\title{
Myb-Binding Protein 1A
}

National Cancer Institute

\section{Source}

National Cancer Institute. Myb-Binding Protein 1A. NCI Thesaurus. Code C33957.

Myb-binding protein 1A (1328 aa, $149 \mathrm{kDa})$ is encoded by the human MYBBP1A gene.

This protein is involved in transcriptional regulation. 